\title{
Omalizumab reduced inhaled corticosteroid use and exacerbations in childhood allergic asthma
}

Milgrom H, Berger W,Nayak A, et al. Treatment of childhood asthma with anti-immunoglobulin E antibody (omalizumab). Pediatrics 2001 Aug;108:e36.

QUESTION: In children with moderate to severe allergic asthma who require daily inhaled corticosteroid (ICS) treatment, is omalizumab (anti-immunoglobulin E [anti-lgE] antibody) more effective than placebo for reducing steroid use and asthma exacerbations?

Design

Randomised \{allocation concealed*\}†, blinded (clinicians, patients \{outcome assessors, and statisticians\} $\uparrow$ ),* placebo controlled trial with 34 weeks of follow up.

\section{Setting}

Research centres in 12 US states and in Washington, DC.

\section{Patients}

334 asthmatic patients who were 6 to 12 years of age (mean age $9 \mathrm{y}, 69 \%$ boys) and whose asthma was well controlled with ICSs (beclomethasone dipropionate [BDP] and bronchodilator treatment) for $\geqslant 3$ months before randomisation. Other inclusion criteria were allergic asthma for $\geqslant 1$ year; positive skin prick test result to $\geqslant 1$ of house dust mite, cockroach, dog, or cat; total serum IgE level between 30 and $1300 \mathrm{IU} / \mathrm{ml}$; body weight $<90 \mathrm{~kg}$; forced expiratory volume at 1 second $\left(\mathrm{FEV}_{1}\right) \geqslant 60 \%$ of predicted normal; $\geqslant 12 \%$ increase in $\mathrm{FEV}_{1}$ from baseline within 30 minutes of taking albuterol; and stable asthma. Exclusion criteria were previous treatment with omalizumab; sinusitis, respiratory tract infection, or lung disease within 1 month or systemic disease within 3 months of randomisation; abnormal findings on an electrocardiogram or a chest radiograph or abnormal laboratory values; or elevated serum IgE concentrations for reasons other than atopy. All patients were analysed for the stable steroid phase and the steroid reduction phase.

\section{Intervention} 150 or $300 \mathrm{mg}$ every 4 weeks; omalizumab 225, 300, or $375 \mathrm{mg}$ every 2 weeks (minimum dose $0.016 \mathrm{IU} / \mathrm{ml}$ per $4 \mathrm{wk})(\mathrm{n}=225)$; or placebo $(\mathrm{n}=109)$. For 16 weeks, the baseline BDP dose was maintained; during the next 8 weeks, BDP was reduced stepwise to establish an effective minimum dose.

Genentech, Inc. and

Novartis

Pharmaceuticals

Corporation.

For correspondence: $D r$ H Milgrom, National Jewish Medical and

Research Center, 1400

Jackson Street, Denver,

CO 80206, USA.

milgromh@njc.org.
Patients were allocated to subcutaneous omalizumab

fewer patients receiving omalizumab $(\mathrm{p}<0.001)$ (table), and the mean number of exacerbations per patient was lower in omalizumab recipients $(0.42 v 0.72, \mathrm{p}<0.001)$.

\section{Conclusion}

In children with moderate to severe allergic asthma requiring daily inhaled corticosteroids, omalizumab reduced corticosteroid use and asthma exacerbations.

*See glossary.

$\dagger$ Information provided by author.

\section{COMMENTARY}

The study by Milgrom $e t a l$ is their second on the use of omalizumab (anti-IgE antibody) in the treatment of asthma and the third published in the previous 3 months that addresses treatment with anti-IgE in large, multicentre asthma studies. Concurrent studies by Busse $e t \mathrm{al}^{1}$ and Soler et $a l^{2}$ included $>500$ adult patients aged 12 to 75 years and used medium- to high-dose inhaled steroids (500 to 1200 $\mu \mathrm{g} / \mathrm{d}$ of beclomethasone). They used a design similar to that of Milgrom $e t a l$ and achieved similar results as regards to steroid reduction and decreases in exacerbations. These studies, along with an earlier publication by Milgrom $\mathrm{et} a l^{3}$ make a case for anti-IgE antibodies as adjunctive treatment for steroid-dependent patients with asthma.

The advantages of anti-IgE over conventional treatments include once or twice monthly subcutaneous injections and its tolerability with infrequent side effects. However, many questions remain. Although the association between asthma and elevated IgE is well established, the actual mechanism by which anti-IgE improves asthma is not known. Whether a role exists for anti-IgE in patients who do not have positive skin test results but who do have elevated $\operatorname{IgE}-$ as is commonly seen in asthma patients - is also unclear. The high placebo response role in these studies needs to be reconciled. Longer term studies ( $\geqslant 12 \mathrm{mo}$ ) must be done to establish whether anti-IgE has a lasting effect on steroid use,

More patients who received omalizumab reduced the

Omalizumab v placebo for childhood allergic asthmał

\begin{tabular}{|c|c|c|c|c|}
\hline Outcomes & Omalizumab & Placebo & $\mathrm{RBI}(95 \% \mathrm{Cl})$ & NNT (Cl) \\
\hline \multirow[t]{2}{*}{$\begin{array}{c}75 \% \text { to } 100 \% \text { reduction in } \\
\text { BDP dose at } 34 \text { weeks }\end{array}$} & $65 \%$ & $50 \%$ & $32 \%$ (8 to 65$)$ & 7 (4 to 23 ) \\
\hline & & & $\operatorname{RRR}(\mathrm{Cl})$ & \\
\hline $\begin{array}{l}\text { Asthma exacerbations at } \\
12 \text { weeks }\end{array}$ & $18 \%$ & $39 \%$ & $53 \%$ (32 to 67$)$ & 5 (4 to 10$)$ \\
\hline
\end{tabular}

$\ddagger \mathrm{BDP}=$ beclomethasone dipropionate. $\mathrm{O}$
lated from information provided by author. enabling it to be used either intermittently or not at all. Such studies must also determine whether anti-IgE can be used as an initial treatment for patients with mild asthma or whether a patient must be stabilised with corticosteroids before being treated with anti-IgE treatment. $\mathrm{BDP}$ dose than did patients who received placebo $(\mathrm{p}=0.002)$ (table). Asthma exacerbations occurred in

Main outcome measures

Reduction of BDP dose and asthma exacerbations. Bruce Mazer, MD
Meakins Christie Laboratories,
Montréal, Quebec, Canada

1 Busse W, Corren J, Lanier Q et al. Omalizumab, anti-IgE recombinant humanized monoclonal antibody, for the treatment of severe allergic asthma. I Allergy Clin Immunol 2001:108:184-90.

2 Soler M, Matz J, Townley R, et al. The anti-IgE antibody omalizumab reduces exacerbations and steroid requirements in allergic asthmatics. Eur Resp J 2001;18:254-61.

3 Milgrom H, Fick RB Jr, Su JQ et al. Treatment of allergic asthma with monoclonal anti IgE antibody. $N$ Engl J Med 1999;341:1966-73. 